\title{
PERBEDAAN MAKNA HIDUP LANSIA YANG TINGGAL DI PANTI WERDHA SENJA CERAH DAN YANG TINGGAL BERSAMA KELUARGA DI DESA
}

\author{
Alicia Benaya Wasti Baris \\ Hendro Bidjuni \\ Sefti Rompas \\ Program Studi Ilmu Keperawatan Fakultas Kedokteran \\ Universitas Sam Ratulangi \\ Email : alicia.b.w.baris@gmail.com
}

\begin{abstract}
Abstrack: The meaning of life is something that is considered very important and valuable, and provides special value for someone and deserves to be a goal in life. Being someone who means and feels valuable in life seems very important when entering the elderly period. At this time, the elderly must be able to accept, be positive and be able to live their old age in peace. The aim is to find out the difference in the meaningoflife of the lives of the elderly who live in nursing home senja cerah and Who Live with Family in Sea Satu Village Pineleng District. The research design used is Observational Analytic with Cross Sectional Study approach. A sample of 30 respondents was obtained using the Purposive Sampling technique. The results of statistical test studies using the T-test at a significance level of 95\%, obtained a significant value $\rho=0.008<\alpha(0.05)$. The conclusion is that there is a difference in the meaningoflife of the lives of the elderly who live in nursing home senja cerah and who live with their families.
\end{abstract}

Keywords : Elderly, Meaning of Life

\begin{abstract}
Abstrak : Makna hidup adalah sesuatu yang dianggap sangat penting dan berharga, serta memberikan nilai khusus bagi seseorang dan layak dijadikan tujuan dalam kehidupan. Menjadi seseorang yang berarti dan merasa berharga dalam hidup tampaknya sangat penting saat memasuki periode lansia. Pada masa ini, lansia harus dapat menerima, bersikap positif serta dapat menjalani masa tuanya dengan tenang Tujuan untuk mengetahui perbedaan makna hidup lansia yang tinggal di panti werdha senja cerah dan yang tinggal bersama keluarga di desa sea satu kecamatan pineleng. Desain penelitian yang digunakan yaitu Observasional Analitik dengan pendekatan Cross Sectional Study. Sampel berjumlah 30 responden yang didapat dengan menggunakan tehnik Purposive Sampling. Hasil penelitian uji statistik menggunakan uji T-test pada tingkat kemaknaan 95\%, didapatkan nilai signifikan $\rho=0,008<\alpha(0,05)$. Kesimpulan ada perbedaan makna hidup lansia yang tinggal di panti werdha senja cerah dan yang tinggal bersama keluarga.
\end{abstract}

Kata kunci : Lansia, Makna Hidup 


\section{PENDAHULUAN}

Menua atau menjadi tua adalah suatu keadaan yang terjadi di dalam kehidupan manusia. Proses menua adalah proses sepanjang hidup, tidak hanya di mulai dari suatu waktu tertentu, tetapi di mulai sejak permulaan kehidupan (Sembiring, 2013). WHO dan UndangUndang Republik Indonesia Nomor 13 tahun 1998 tentang kesejahteraan lansia bab 1 pasal 1 ayat 2 bahwa lansia adalah orang yang telah mencapai usia 60 tahun ke atas dan karena proses menua akan mengalami banyak keterbatasan sehingga memerlukan bantuan dalam kesejahteraan kesehatan dan sosial (Depkes RI, 2017).

Lansia adalah periode penutup dalam rentang hidup seseorang, yaitu suatu periode dimana seseorang telah "beranjak jauh" dari periode terdahulu yang lebih menyenangkan atau beranjak dari waktu yang penuh dengan manfaat Lanjut usia adalah bagian dari proses tumbuh kembang. Manusia tidak secara tiba-tiba menjadi tua, tetapi berkembang dari bayi, anak-anak dewasa dan akhirnya menjadi tua. Hal ini normal, dengan perubahan fisik dan tingkah laku yang dapat diramalkan yang terjadi pada semua orang pada saat lansia mencapai usia tahap perkembangan kronologis tertentu (Azizah, 2011). Diseluruh dunia jumlah lansia diperkirakan ada 500 juta dengan rata- rata usia 60 tahun dan diperkirakan pada tahun 2025 akan mencapai 1,2 milyar (Bandiyah, 2009). Pertumbuhan populasi lansia (usia > 60 tahun) di dunia meningkat sangat pesat dibandingkan dengan kelompok usia lain. Pada tahun 2000 jumlah lansia di dunia sekitar 600 juta (11\%), tahun 2025 diperkirakan meningkat menjadi 1,2 milyar (22\%) dan tahun 2050 meningkat menjadi 2 milyar. Di negara berkembang juga memperlihatkan peningkatan jumlah lansia pada tahun 2025 diperkirakan mancapai 840 juta $(70 \%)$ dan tahun 2050 jumlah lansia akan mancapai 1,6 milyar (80\%) (Sembiring, 2013).
Menurut World Heath Organization (WHO), populasi lanjut usia (Lansia) di indonesia, yaitu penduduk usia diatas 60 tahun diperkirakan menjadi dua kali lipat dari $12 \%$ dan akan bertambah menjadi 22\% tahun 2050, dari 900 juta jiwa akan bertambah menjadi 2 miliar di tahun 2050 (WHO, 2014). Secara keseluruhan jumlah lansia di Indonesia juga berada di urutan keempat di dunia yaitu berjumlah 20,24 juta jiwa setara dengan $8,03 \%$ dari seluruh penduduk indonesia. Sulawesi Utara merupakan urutan kelima penduduk lansia terbanyak se-Indonesia, jumlah lansia di Kota Manado sebanyak 20,391 jiwa (Dinas Kesehatan Manado, 2014). Jumlah lanjut usia di Propinsi Sulawesi Utara hingga september 2014 berjumlah 665.279 jiwa (Kanender, 2015). Jumlah keseluruhan lansia yang ada di Panti Werdha Senja Cerah Manado 55 jiwa dan di Desa Sea 1 Kecamatan Pineleng berjumlah 51 jiwa. Lansia merupakan hal yang akan dihadapi oleh semua orang ketika mengakhiri usia madya sehingga ada perubahan-perubahan khas yang dialami oleh lansia.

$$
\text { Santoso \& Wijaya }
$$
mengatakan sebagian besar perubahan kondisi fisik yang terjadi pada usia lanjut terjadi ke arah yang memburuk, seperti mengerasnya tulang-tulang, menumpuknya garam mineral dan modifikasi pada susunan organ tulang sehingga bisa mengakibatkan tulang mengapur dan mudah retak/patah (osteoporosis). Selain perubahan fisik yang terjadi, lansia juga mengalami perubahan sosial dan ekonomi. Perubahan sosial ditandai dengan perubahan peran dan meninggalnya pasangan/kerabat/teman-teman sedangkan perubahan ekonomi ditandai dengan ketergantungan secara finansial pada dana pensiun dan penggunaan waktu luang sebagai seorang pensiun (Santoso \& Wijaya, 2014).

Perubahan-perubahan di atas yang kadangkala menyebabkan keluarga tidak memberikan tempat bagi lansia. 
Cahyawati, (2004) menjelaskan bahwa keberadaan lansia masih menjadi beban bagi keluarga dan masyarakat sehingga mendorong sebagian masyarakat untuk menempatkan lansia di panti werdha (tempat huni untuk orang lanjut usia). Cahyawati, (2004) menambahkan bahwa lansia yang tinggal di panti werdha memiliki sisi positif dan negatif. Sisi positifnya adalah sosialisasi di lingkungan dengan rekan/teman usia sebaya dapat memberikan kesenangan pada lansia sehingga bisa menutupi rasa kesepian yang biasanya dialami mereka. Namun sebaliknya, lansia juga bisa merasa tersisihkan atau tidak dianggap oleh keluarga yang menitipkan mereka di sana. Perasaan kesepian dan tersisihkan yang dirasakan oleh lansia bisa mempengaruhi bagaimana ia memaknai dirinya dan pengalaman hidup yang sudah pernah dilaluinya (Santoso \& Wijaya, 2014).

Makna hidup adalah sesuatu yang dianggap sangat penting dan berharga, serta memberikan nilai khusus bagi seseorang dan layak dijadikan tujuan dalam kehidupan. Makna hidup seseorang dan apa yang bermakna bagi dirinya biasanya bersifat khusus dan berbeda dengan orang lain. Menjadi seseorang yang berarti dan merasa berharga dalam hidup tampaknya sangat penting saat memasuki periode lansia. Pada masa ini, lansia harus dapat menerima, bersikap positif serta dapat menjalani masa tuanya dengan tenang. Makna hidup lansia berkaitan dengan persepsi terhadap kualitas hidup, yang mencakup kesejahteraan psikologis, fungsi fisik yang baik, hubungan dengan orang lain, kesehatan dan aktivitas sosial. Memiliki makna hidup berarti dapat meningkatkan semangat hidup dan meletakkan dasar untuk kesejahteraan yang nantinya membawa kebahagiaan pada diri lansia (Steger \& Michael, 2011).

Berdasarkan hasil pengambilan data awal yang di lakukan di Panti Werdha BPLU Senja Cerah Manado dan di Desa Sea 1 Kecamatan Pineleng di dapatkan jumlah lansia yang tinggal di panti Werdha
BPLU Senja Cerah Manado sebanyak 23 orang, yang terdiri dari perempuan 19 orang dan 6 orang laki-laki dan lansia yang tinggal di Desa Sea 1 Kecamatan Pineleng yaitu 17 orang dimana terdiri dari 13 orang perempuan dan 4 orang laki-laki. Hasil wawancara yang peneliti lakukan pada lansia yang berada di Panti Werdha Senja Cerah Manado, dari 9 orang diantaranya 5 lansia mereka mengatakan kecewa karena keluarga jarang menjenguk dan mereka juga mengatakan pasrah dengan kondisi kehidupan mereka saat ini, sedangkan hasil wawancara yang dilakukan peneliti di Desa Sea 1 Kecamatan Pineleng didapatkan 6 lansia mengatakan senang karena keluarganya masih memperhatikan dan mengurus mereka dengan baik, sedangkan 2 lansia lainnya mengatakan sejak ditinggalkan pasangan dan kehilangan pekerjaan mereka menjadi kesepian dan mereka tetap bersyukur dengan keadaan dan kondisi mereka. Sehingga, berdasarkan hal diatas saya tertarik untuk melakukan penelitian mengenai "Perbedaan Makna Hidup Lansia Yang Tinggal di Panti Werdha Senja Cerah Manado dan Yang Tinggal di Desa Sea 1 Kecamatan Pineleng".

\section{METODE PENELITIAN}

Penelitian ini termasuk dalam jenis penelitian kuantitatif dengan menganalisis gambaran perbedaan antara kedua variabel yaitu variabel independen (makna hidup lansia yang tinggal di panti werdha) dan variabel dependen (makna hidup lansia yang tinggal di desa sea 1). Penelitian ini menggunakan jenis penelitian Observasional analitik, dengan pendekatan cross sectional study. Penelitian ini dilaksanakan di Panti Werdha Senja Cerah Manado dan Desa Sea 1 Kecamatan Pineleng pada bulan Agustus 2019. Populasi penelitian ini adalah seluruh lansia yang ada di panti werdha senja cerah manado dan lansia yang berada di desa sea 1 kecamatan pineleng dengan jumlah 30 lansia. Teknik pengambilan sampel dalam penelitian ini menggunakan Probability 
Sampel dan dengan menggunakan metode Purposive Sampling dengan total 15 lansia di panti werdha dan 15 lansia di desa sea 1. (Notoadmodjo, 2010).Instrumen penelitian yang digunakan untuk mengukur variabel makna hidup lansia menggunakan kuesioner yang digunakan sebelumnya oleh Nauli, (2011).uji yang digunakan adalah uji $\mathrm{T}$ dengan nilai sig (saphiro wilk) 0,407 dan menggunakkan dua sampel yang berbeda yaitu lansia yang ada di panti werdha dan lansia yyang tinggal bersama keluarga sehingga diperoleh hasil $\mathrm{p}$ value $=$ $0,008<0,05$. Kuesioner ini terdiri dari 10 pernyataan. ya $=2$, kadang-kadang $=1$, tidak $=0$. Setelah lembar kuesioner diisi oleh responden, kemudian dilakukan penghitungan skor dengan cara menjumlahkan skor tiap pertanyaan.

Pengolahan data yang diperoleh dari hasil penelitian ini diolah secara manual dengan mengelompokkan hasil observasi kemudian dilakukan penghitungan skor dan dianalisis menggunakan uji statistik melalui sistem komuterisasi dengan beberapa tahap yaitu editing, coding, cleaning, tabulating (Notoatmodjo, 2010). Analisa bivariat dalam penelitian ini yaitu untuk mengetahui Perbedaan Makna Hidup Lansia Yang Tinggal di Panti Werdha Senja Cerah Manado dan Yang Tinggal di Desa Sea 1 Kecamatan Pineleng. Peneliti menggunakan uji statistic T-test dengan tingkat kemaknaan $95 \%(\alpha=0,05)$.

\section{HASIL dan PEMBAHASAN}

\section{Karakteristik Responden}

Tabel 1. Distribusi Responden Berdasarkan Jenis Kelamin

\begin{tabular}{ccc}
\hline Jenis Kelamin & n & \% \\
\hline Laki-laki & 10 & 33,3 \\
Perempuan & 20 & 66,7 \\
\hline Total & $\mathbf{3 0}$ & $\mathbf{1 0 0}$ \\
\hline
\end{tabular}

Berdasarkan hasil penelitian 30 responden didapatkan mayoritas responden adalah berjenis kelamin perempuan sebanyak 20 responden $(66,7 \%)$ sedangkan laki-laki sebanyak 10 responden $(33,3 \%)$.
Penelitian ini sejalan dengan penelitian yang dilakukan oleh Putri, dkk (2014) yang berjudul kualitas hidup lansia yang tinggal bersama keluarga dan di panti dengan jumlah sampel 160 responden dengan mayoritas berjenis kelamin perempuan yaitu sebanyak 119 responden $(59,0 \%)$.

Tabel 2. Distribusi Responden Berdasarkan Usia

\begin{tabular}{ccc}
\hline Usia & n & \% \\
\hline 60-70 Tahun & 11 & 36,7 \\
71-80 Tahun & 8 & 26,7 \\
>80 Tahun & 11 & 36,7 \\
\hline Total & $\mathbf{3 0}$ & $\mathbf{1 0 0}$ \\
\hline
\end{tabular}

Hasil penelitian yang dilakukan pada 30 responden didapatkan mayoritas responden berusia 60-70 tahun yaitu sebanyak 11 orang $(36,7 \%)$, dan $>80$ tahun sebanyak 11 orang $(36,7 \%)$, dan rentang usia paling sedikit yaitu 71-80 tahun sebanyak 8 orang $(26,7 \%)$. Hasil penelitian ini sejalan dengan penelitian yang di lakukan oleh Putri, dkk (2014) yang berjudul kualitas hidup lansia yang tinggal bersama keluarga dan di panti dengan jumlah sampel 160 responden di dapatkan usia responden mayoritas berusia 60 - 89 tahun.

\section{Analisa Univariat}

Tabel 3. Distribusi dan Presentase Makna Hidup Lansia Yang Tinggal Di Panti Werdha Senja Cerah

\begin{tabular}{ccc}
\hline Kategori & $\mathbf{n}$ & $\mathbf{\%}$ \\
\hline Kurang Bermakna & 10 & 58,8 \\
Bermakna & 5 & 38,5 \\
\hline Total & $\mathbf{1 5}$ & $\mathbf{1 0 0}$ \\
\hline
\end{tabular}

Tabel 3 menunjukan hasil penelitian yang dilakukan di Panti Werdha Senja Cerah dengan jumlah responden 15 orang, sebanyak 10 responden $(58,8 \%)$ memiliki makna hidup kurang bermakna. Sedangkan 5 responden $(38,5 \%)$ dalam kategori bermakna. Hal ini menandakan bahwa makna hidup lansia yang ada di panti werdha kebanyakan adalah yang 
kurang bermakna. Hal ini sejalan dengan penelitian Putri, dkk (2014) yang memiliki hasil $68,8 \%$ responden memiliki makna hidup yang kurang bermakna.

Hasil observasi selama penelitian berlangsung bahwa lansia yang tinggal di Panti Werdha kurang mendapatkan dukungan keluarga bahkan cenderung tidak mendapat dukungan keluarga, berbeda dengan lansia yang tinggal dengan keluarga, mereka mengemukakan bahwa mereka mendapat cukup dukungan keluarga sehingga kualitas hidup mereka baik. Menurut Yeni (2011), bahwa dukungan keluarga sangat bermanfaat bagi kehidupan lansia.

Lansia yang tinggal di panti werdha memiliki makna hidup yang kurang bermakna dikarenakan kurang mendapatkan dukungan sosial hal ini di buktikan dari pendapat Lee (2015) yang mengatakan bahwa dukungan sosial menjadi salah satu faktor yang mempengaruhi kebermaknaan hidup seorang lansia. Lansia yang hidup di panti werdha mengharuskan lansia tersebut untuk tinggal jauh dari keluarganya. Para lansia ini hidup dalam keterasingan, dan kesepian yang menginginkan dukungan sosial maupun dukungan dari keluarganya.

Tabel 4. Distribusi dan Presentase Makna Hidup Lansia Yang Tinggal Di Desa Sea Satu

\begin{tabular}{ccc}
\hline Kategori & n & \% \\
\hline Kurang Bermakna & 7 & 41,2 \\
Bermakna & 8 & 61,5 \\
\hline Total & $\mathbf{1 5}$ & $\mathbf{1 0 0}$ \\
\hline
\end{tabular}

Berdasarkan hasil penelitian yang dilakukan di Desa Sea Satu dengan jumlah responden 15 orang, sebanyak 8 responden $(61,5 \%)$ memiliki makna hidup dalam kategori bermakna. Sedangkan 7 responden $(41,2 \%)$ memiliki makna hidup dalam kategori kurang bermakna. Hal ini menandakan bahwa makna hidup lansia yang tinggal bersama keluarga di Desa Sea Satu memiliki keluarga yang bahagia di buktikan dengan makna hidup lansia yang bermakna. Hal ini sejalan dengan penelitian Indriyani, dkk (2014) yang berjudul Subjective Well-Being..

Hasil penelitian menunjukkan bahwa makna hidup pada lansia berada pada kategori bermakna. Hal ini dimungkinkan, karena para lansia yang masih tinggal bersama keluarga cenderung dapat melakukan segala macam aktivitas keseharian bersama keluarga dengan mendapatkan dukungan langsung dari keluarganya, sehingga salah satu yang dapat lansia di rumah lakukan adalah menyesuaikan diri, terlibat penuh dalam aktivitas, teman/sahabat dan saudara/anak, serta interaksi dengan masyarakat di sekitar tempat tinggal (Indriyani, dkk 2014).

Tempat tinggal memiliki makna dorongan sosial. Setiap orang membutuhkan dorongan sosial, karena dorongan sosial berfungsi untuk mengembalikan keseimbangan psikis dalam menghadapi problem hidup. Karena itu, jelas dorongan sosial memiliki kaitan dengan kesehatan dan kebahagiaan, serta kebermaknaan hidup dari seorang lansia.

\section{Analisa Bivariat}

Tabel 5. Perbedaan Makna Hidup Lansia Yang Tinggal Di Panti Werdha Senja Cerah Dan Yang Tinggal Bersama Keluarga Di Desa Sea Satu Kecamatan Pineleng

\begin{tabular}{|c|c|c|c|c|c|c|c|}
\hline \multirow{3}{*}{$\begin{array}{l}\text { Makna } \\
\text { Hidup } \\
\text { Lansia }\end{array}$} & \multicolumn{4}{|c|}{ Tempat Tinggal } & \multirow{2}{*}{\multicolumn{2}{|c|}{ Total }} & \multirow{3}{*}{$\mathbf{P}$} \\
\hline & \multicolumn{2}{|c|}{$\begin{array}{c}\text { Panti } \\
\text { Werdha }\end{array}$} & \multicolumn{2}{|c|}{$\begin{array}{c}\text { Desa Sea } \\
\text { satu }\end{array}$} & & & \\
\hline & $\mathrm{n}$ & $\%$ & $\mathrm{n}$ & $\%$ & $\mathrm{n}$ & $\%$ & \\
\hline $\begin{array}{c}\text { Kurang } \\
\text { Bermakna }\end{array}$ & 10 & 58,8 & 7 & 41,2 & 17 & 100 & \multirow{2}{*}{0,008} \\
\hline Bermakna & 5 & 38,5 & 8 & 61,5 & 13 & 100 & \\
\hline Total & 15 & 50,0 & 15 & $\mathbf{5 0 , 0}$ & 30 & 100 & \\
\hline
\end{tabular}

Analisa Perbedaan makna hidup lansia yang tinggal di panti werdha senja cerah dengan lansia yang tinggal bersama keluarga di desa sea satu dengan hasil uji menggunakan uji T-test di peroleh $\rho$ value $=0,008<0,05$ yang di hitung dari hasil uji normalitas data menggunakan sig 0,407 di 
karenakan data yang di dapat adalah normal (Notoadmodjo, 2012). Hal ini menunjukan terdapat perbedaan yang signifikan antara makna hidup lansia yang tinggal di panti werdha senja cerah dengan lansia yang tinggal bersama keluarga di desa sea satu. Hasil penelitian ini sejalan dengan penelitian yang dilakukan oleh Ferdian (2016) yang berjudul Perbedaan Makna Hidup Pada Lansia Yang Tinggal Di Panti Werdha Dengan Yang Tinggal Bersama Keluarga, didapatkan hasil signifikan $(\rho) \quad 0,012 \quad(<0,05)$ terdapat Perbedaan Antara Makna Hidup Pada Lansia Yang Tinggal Di Panti Werdha Dengan Yang Tinggal Bersama Keluarga.

Penelitian ini ditemukan $7(41,2 \%)$ lansia yang tinggal di desa sea bersama keluarga memiliki makna hidup yang adalah kurang bermakna. Hal ini di karenakan lingkungan tempat tinggal yang hanya berada di rumah bersama keluarga mengakibatkan peran lansia dalam menyesuaikan diri dengan keadaan di luar rumah atau sosialisasi bersama teman sesama lansia menjadi kurang sehingga kebanyakan lansia menjadi jenuh ketika berada di rumah (Nuryanti, 2012). Bagi lansia, teman seumuran atau teman sesama lansia akan dapat meningkatkan produktivitas yang di miliki sehingga dapat berinteraksi dengan lansia yang lain untuk memperoleh perasaan yang memiliki suatu kelompok yang memungkinkannya membagi minat, serta melakukan kegiatan yang sifatnya kreatif secara bersama-sama di dalam suatu komunitas lansia di panti werdha (Fitria, 2011).

Lansia yang tinggal bersama keluarga, cenderung merasa di perlakukan dengan baik oleh keluarganya, mereka masih merasa di hargai dan merasa pantas untuk hidup, tidak di abaikan oleh keluarga dan mereasa bahagia bisa tinggal bersama keluarga yang mereka punya. Berbeda halnya dengan lansia yang tinggal di panti werdha justru merasakan bahwa ada bagian dari dalam hidup mereka yang tidak terpenuhi, yaitu kehadiran keluarga di tengah-tengah kehidupannya. Menurut
Ahmad (2014), dukungan keluarga inti dari para lansia merupakan sistem pendukung yang berarti sehingga dapat memberikan pentujuk tentang kesehatan mental, fisik, dan emosional bagi para lansia. Dukungan seperti inilah yang tidak didapat dari lansia yang tinggal di panti werdha, justru mereka menyatakan bahwa kurangnya kepuasan batin yang di rasakan ketikan mereka memperoleh dukungan sosial yang diberikan oleh para teman-temannya ataupun pengurus panti (Ferdian, 2016). Hal ini sejalan dengan penelitian yang dilakukan Sutikno, (2011) yang mengemukakan bahwa lansia sangat membutuhkan dukungan karena terdapat hubungan yang signifikan antara makna hidup lansia dan dukungan keluarga.

\section{SIMPULAN}

Makna Hidup Lansia yang Paling bermakna yaitu lansia yang tinggal bersama keluarga di bandingkan dengan lansia yang tinggal di desa sea satu sehingga terdapat perbedaan antara makna hidup lansia di panti werdha dan di desa sea satu.

\section{DAFTAR PUSTAKA}

Ahmad. (2014). Gambaran Dukungan Keluarga Dalam Pemenuhan Aktivitas Sehari-Hari Lansia Di Desa Tongko Kecamatan Baroko Kabupaten Enrekang. Universitas Islam Negeri Makasar. (skripsi hal:3)

Azizah.(2011). Keperawatan Lanjut usia.Yogyakarta: Graha Ilmu. (hal:29)

Bandiyah. (2009). Lanjut Usia dan Keperawat Gerontik. Yogyakarta: Nuha Medika (hal:24).

Cahyawati, C. (2004). Perbedaan Makna Hidup Pada Lansia Yang Tinggal Di Panti Werdha Dengan Yang Tinggal Bersama Keluarga. Bekasi. (skripsi hal:4) 
Departemen Kesehatan Republik Indonesia. (2017). Analisis Lansia Indonesia. $\quad$ www.depkes.go.id. Diakses : juli, pukul 17:00 WITA.

Dinas Kesehatan Kota Manado. (2014). Jumlah Lansia Kota Manado.

Ferdian, E., H. (2016). Perbedaan Makna Hidup Lansia Yang Tinggal Di Panti Werdha Dengan Yang Tinggal Bersama Keluarga. UKSW. (skripsi hal:4)

Fitria. (2011). Interaksi Sosial Dan Kualitas Hidup Lansia Di Panti Werdha UPT Pelayanan Sosial Lanjut Usia Dan Anak Balita Binjai. Fakultas Ilmu Keperawatan Universitas Padjadjaran. (skripsi hal:5)

Indriyani, dkk. (2014). Subjective WellBeing Pada Lansia Di Tinjau Dari Tempat Tinggal. Jurusan Psikologi Universitas Negeri Semarang. (vol;3 no:1) (hal:3)

Kanender, Y. (2015). Pengaruh Terapi Relaksasi Otot Progresif Terhadap Perubahan Tingkat Insomnia Pada Lansia di Panti Werdha Manado. Program Studi Ilmu Keperawatan Fakultas Kedokteran Unsrat.(vol:3 no: 1) (hal:2)

Lee, Su-jin, Ok-Hee Ahn \& Hye-Gyeong Cha. (2015). Factors Influencing The Meaning In Life In The Old Age. Indian Journal of Science and Technology. Republic Of Korea.(vol:8)(hal:2)

Nauli. (2011). Pengaruh Logoterapi Lansia Dan Psikoedukasi Keluarga Terhadap Depresi Dan Kemampuan Memaknai Hidup Pada Lansia Di Keluarahan Katulampa Bogor. Timur. Fakultas Ilmu Keperawatan Universitas Indonesia. .(skripsi hal:315)
Notoadmodjo, S. (2012). Metodologi penelitian kesehatan. Jakarta : Rineka Cipta. (hal:180)

Notoadmodjo, S. (2010). Metodologi penelitian kesehatan. Jakarta : Rineka Cipta. (hal:150)

Nuryanti, T. (2012). Hubungan Perubahan Peran Diri Dengan Tingkat Depresi Lansia Yang Tinggal di UPT PSLU Pasuruan. (vol:8 no:1) (hal:2)

Putri, S., Fitriana. (2014). Kualitas Hidup Lansia Yang Tinggal Bersama Keluargan dan Panti. Universitas Pendidikan Indonesia. (hal:2)

Santoso, M. R., Wijaya, S. V. (2014). Gambaran Makna Hidup Pada Lansia Yang Tinggal Di Panti Werdha. Universitas Bunda Mulia. (vol:7no:1)hal:1-2)

Sembiring, S., M. (2013). Hubungan Dukungan Sosial Keluarga Dan Status Kesehatan Dengan Gejala Depresi Pada Lansia Yang Tinggal Di UPT Pelayanan Sosial Wilayah Binjai Medan. Fakultas Kesehatan Masyarakat Universitas Sumatera (skripsi hal:13)

Steger \& Michael, F. (2011). Is A Life Without Meaning Satisfying? The Moderating Role Of The Search Foe Meaning In Satisfication With Life Judgement. The Journal of Positive Psychology.(vol:6 no:2)

Sutikno, E. (2011). Hubungan Antara Fungsi Keluarga Dan Kualitas Hidup Lansia. Jurnal Kedokteran Indonesia. (vol:11no:1) (hal:3)

WHO. (2014). Mental Health Of Older Adult. http://www.who.int/enity/mediacen tre. 
Yeni. (2011). Hubungan Antara Dukungan Keluarga Dan Karakteristik Lansia Dengan Kejadian Stroke Pada Lansia Hipertensi Di Wilayah Kerja Puskesmas Perkotaan Bukit Tinggi. Pasca Sarjana Ilmu Keperawatan Depok.(skripsi hal:14-15) 